\title{
PENCATATAN DATA TRANSAKSI KEUANGAN PADA USAHA MIKRO DAN KECIL: STUDI KASUS DI KAMPUNG ROTI SURABAYA
}

\author{
Setiadi Alim Lim ${ }^{1}$ \\ setiadi@staff.ubaya.ac.id \\ Galuh Artika Febriyanti ${ }^{2}$ \\ galuh.af@staff.ubaya.ac.id
}

\begin{abstract}
Research from Dawuda and Azeko (2015) in Bolgatanga Municipality, Ghana found that $75 \%$ of small businesses do not record financial transactions and only $25 \%$ have recorded financial transactions. This study aims to examine whether 75\% of micro and small enterprises such as the findings of Dawuda and Azeko (2015) do not record financial transaction data. In addition, it will also be examined whether the recording of financial transactions data according to micro and small enterprises is useful or not to measure business performance, the need to apply for credit and tax purposes.

The object of research is micro and small business in Kampung Roti, Surabaya. From population of 65 micro and small enterprises in Kampung Roti, Surabaya taken 38 micro and small enterprises as sample. The results

showed that 75\% ofmicro and small enterprises did not record financial transaction data. According to $75 \%$ of micro and small enterprises recording financial transaction data does not provide benefits to measure business performance, the need to apply for credit and tax purposes. There is a relationship between the decision of micro and small enterprises to do or not to record financial transaction data with measuring business performance, the need to apply for credit and tax purposes.
\end{abstract}

Keywords : Micro and Small Enterprises, financial transactions, accounting

\section{Pendahuluan}

Sektor bisnis mikro, kecil dan menengah memegang peranan yang penting dalam struktur ekonomi nasional suatu negara, baik ekonomi nasional di negara-negara maju maupun negara-negara berkembang.
Pada negara-negara berkembang peranan bisnis mikro, kecil dan menengah ini jauh lebih vital lagi dalam rangka memacu pertumbuhan ekonominya. Walaupun jumlah tenaga kerja yang terlibat pada setiap usaha mikro, kecil dan menengah tidak

1,2 Dosen Program Studi D3 Akuntansi Politeknik Ubaya, Surabaya. 
banyak jumlahnya, tetapi karena jumlah usaha mikro, kecil dan menengah ini relatif sangat banyak, maka jumlah tenaga kerja yang terlibat di usaha mikro, kecil dan menengah relatif sangat besar.

Pada negara-negara berkembang umumnya sebagian besar tenaga kerja yang ada mempunyai tingkat pendidikan yang rendah dan belum memiliki keterampilan yang memadai. Jadi walaupun roda ekonomi berjalan dengan baik dengan bertumbuhnya berbagai bisnis dan industri, namun penyerapan tenaga kerja pada bisnis dan industri ini masih sangat kecil, karena tenaga kerja yang ada sebagian besar tidak memenuhi tingkat pendidikan minimum dan keterampilan yang memadai. Dalam kondisi demikian, maka usaha mikro, kecil dan menengah menjadi jawaban bagi tenaga kerja yang tidak memiliki tingkat pendidikan yang cukup dan keterampilan yang memadai tersebut.

Perkembangan usaha mikro, kecil dan menengah di Indonesia sangat pesat sekali. Bellefleur et al. (2012) menyatakan bahwa pada tahun 2009 dan 2010 usaha yang ada di Indonesia 99,99\% berupa usaha mikro, kecil dan menengah dengan memberikan kontribusi pada Produk Domestik Bruto (PDB) sebesar 56,53\% pada tahun 2009 dan $57,12 \%$ pada tahun 2010 , sedangkan sisanya sebesar $0,01 \%$ usaha yang merupakan usaha besar dengan memberikan kontribusi pada Produk Domestik Bruto (PDB) sebesar $43,47 \%$ pada tahun 2009 dan $42,88 \%$ pada tahun 2010. Hal senada diungkapkan oleh IFC (2016) yang menyatakan bahwa 99\% usaha di Indonesia merupakan usaha mikro, kecil dan menengah, mempekerjakan 89\% tenaga kerja di sektor swasta dan berkontribusi terhadap 57\% dari Produk Domestik Bruto (PDB). Data ini menunjukkan bahwa usaha mikro, kecil dan menengah di Indonesia memegang peranan yang sangat strategis dalam pengembangan ekonomi nasional berkaitan dengan kontribusinya pada
Produk Domestik Bruto (PDB) dan dalam menyerap tenaga kerja.

Untuk dapat berkembang, usaha mikro, kecil dan menengah ini harus mampu meningkatkan kemampuan manajerialnya. Madurapperuma et al. (2016) menyatakan harus diakui bahwa informasi akuntansi yang layak adalah penting bagi manajemen yang sukses dan ini berlaku untuk semua entitas bisnis, baik yang besar maupun yang kecil.

Informasi keuangan ini bermanfaat sebagai dasar manajemen untuk mengambil keputusan internal, kepentingan pengajuan proposal kredit ke bank dan lembaga keuangan lainnya serta keperluan perpajakan. Ikem et al. (2012) menyatakan, baru-baru ini, praktik bank di seluruh dunia menunjukkan informasi akuntansi yang dipertimbangkan sebagai dasar mengevaluasi usaha kecil dan menengah untuk tujuan mengakses dana dari bank.

Penelitian ini dimaksudkan untuk mengetahui apakah usaha mikro dan kecil di Kampung Roti, Surabaya telah melakukan proses akuntansi berupa pencatatan data transaksi keuangan. Di samping itu juga akan diteliti apakah bagi usaha mikro dan kecil, informasi keuangan tersebut dianggap penting dan dapat dimanfaatkan untuk berbagai keperluan seperti mengukur kinerja usaha, keperluan mengajukan kredit dan keperluan perpajakan. Kemudian akan coba dilihat apakah ada hubungan antara pencatatan data transaksi keuangan dengan keperluan untuk mengukur kinerja usaha, keperluan mengajukan kredit, dan keperluan perpajakan.

\section{Perumusan Masalah}

Masalah yang ada dalam penelitian ini dapat dirumuskan sebagai berikut:

1. Apakah usaha mikro dan kecil di Kampung Roti, Surabaya telah melakukan pencatatan data transaksi keuangan? 
2. Apakah bagi usaha mikro dan kecil di Kampung Roti, Surabaya pencatatan data transaksi keuangan secara signifikan bermanfaat untuk mengukur kinerja usaha?

3. Apakah bagi usaha mikro dan kecil di Kampung Roti, Surabaya pencatatan data transaksi keuangan secara signifikan bermanfaat untuk mengajukan kredit?

4. Apakah bagi usaha mikro dan kecil di Kampung Roti, Surabaya pencatatan data transaksi keuangan secara signifikan bermanfaat untuk keperluan perpajakan?

5. Apakahadahubungan antara pencatatan data transaksi keuangan dengan mengukur kinerja usaha?

6. Apakah ada hubungan antara pencatatan data transaksi keuangan dengan keperluan mengajukan kredit?

7. Apakahadahubungan antara pencatatan data transaksi keuangan dengan keperluan perpajakan?

\section{Tinjauan Pustaka}

NCR (2011) telah melakukan pengumpulan data mengenai batasan definisi usaha mikro, kecil, dan menengah dari beberapa negara yang setelah dikombinasikan dengan sumber dari EG (2012) seperti terlihat pada Tabel 1. Di Indonesia batasan mengenai usaha mikro, kecil, dan menengah diatur dalam Undang-Undang Nomor 20 Tahun 2008 tentang Usaha Mikro, Kecil, dan Menengah (selanjutnya disebut UndangUndang UMKM) pasal 6 ayat (1), ayat (2) dan ayat (3) yang mengatur tentang kriteria usaha mikro, usaha kecil, dan usaha menengah. Parameter yang dipakai Indonesia untuk mengelompokkan usaha menjadi usaha mikro, kecil, dan menengah hanya ada 2, yaitu kekayaan bersih di luar tanah dan bangunan tempat usaha serta jumlah penjualan.

Mengenai pentingnya peranan akuntansi di dalam bisnis, Dawuda and Azeko (2015) menyatakan sistem pencatatan keuangan yang baik menjadi bagian terintegrasi dari manajemen usaha kompetitif saat ini dan di dalam lingkungan bisnis yang penuh tantangan.

Yang perlu diingat bahwa pembukuan dan akuntansi mempunyai dua tujuan dasar: pertama, untuk melacak pendapatan dan pengeluaran, yang meningkatkan peluang menghasilkan keuntungan; dan kedua, untuk mengumpulkan informasi keuangan yang diperlukan untuk mengisi berbagai Surat Pemberitahuan (SPT) Pajak (Burns, 1999 dalam Akesinro and Adetoso, 2016).

Tabel 1. Sinopsis dari Definisi SME Per Region

\begin{tabular}{|c|c|c|c|c|c|c|c|c|c|c|}
\hline \multicolumn{6}{|c|}{ VARIOUS COUNTRIES } & \multicolumn{5}{|c|}{ BRIC COUNTRIES } \\
\hline & $\mathrm{EU}$ & USA & $\begin{array}{c}\text { Asia } \\
\text { (Malaysia) }\end{array}$ & Egypt & Ghana & $\begin{array}{c}\text { Brazil } \\
\text { (Commercial) }\end{array}$ & Russia & India & China & RSA \\
\hline & $\begin{array}{l}\text { Small and } \\
\text { Medium } \\
\text { Enterprise }\end{array}$ & $\begin{array}{l}\text { Small and } \\
\text { Medium } \\
\text { Business }\end{array}$ & $\begin{array}{l}\text { Small and } \\
\text { Medium } \\
\text { Enterprise }\end{array}$ & $\begin{array}{c}\text { Micro, } \\
\text { Small and } \\
\text { Medium } \\
\text { Enterprise } \\
\end{array}$ & $\begin{array}{c}\text { Micro, Small } \\
\text { and Medium } \\
\text { Enterprise }\end{array}$ & $\begin{array}{l}\text { Small and } \\
\text { Medium } \\
\text { Enterprise }\end{array}$ & $\begin{array}{l}\text { Small and } \\
\text { Medium } \\
\text { Enterprise }\end{array}$ & $\begin{array}{c}\text { Micro, } \\
\text { Small and } \\
\text { Medium } \\
\text { Enterprise } \\
\end{array}$ & $\begin{array}{l}\text { Small and } \\
\text { Medium } \\
\text { Enterprise }\end{array}$ & $\begin{array}{l}\text { Small and } \\
\text { Medium } \\
\text { Enterprise }\end{array}$ \\
\hline \multicolumn{11}{|c|}{ Number of employees } \\
\hline Micro & $<10$ & - & $<5$ & $1-4$ & $1-5$ & $1-9$ & - & 0 & 0 & $<20$ \\
\hline Small & $<50$ & $<100$ & $5-50$ & $5-14$ & 6-29 & $10-49$ & $15-100$ & 0 & $<300$ & $50-99$ \\
\hline Medium & $<250$ & $<500$ & $51-150$ & $15-49$ & $30-99$ & $50-99$ & $101-250$ & 0 & $300-2000$ & $100-200$ \\
\hline \multicolumn{11}{|c|}{ Annual Turnover } \\
\hline Micro & $<€ 2 \mathrm{~m}$ & 0 & $\begin{array}{c}< \\
\text { RM250.000 }\end{array}$ & 0 & $\$ 10 \mathrm{k}$ & 0 & 0 & $<$ Rs50m & 0 & $<\mathrm{R} 150 \mathrm{k}$ \\
\hline Small & $<€ 10 \mathrm{~m}$ & 0 & $\begin{array}{l}\mathrm{RM} \\
250.000- \\
<\mathrm{RM} 10 \mathrm{~m}\end{array}$ & 0 & $\$ 100 \mathrm{k}$ & 0 & $\begin{array}{l}\text { 400m } \\
\text { RUB nax }\end{array}$ & $\begin{array}{l}\text { Rs50- } \\
60 \mathrm{~m}\end{array}$ & $<\mathrm{Y} 30$ & $\begin{array}{l}\mathrm{R} 2 \mathrm{~m}- \\
\mathrm{R} 4,5 \mathrm{~m}\end{array}$ \\
\hline Medium & $<€ 50 \mathrm{~m}$ & 0 & $\begin{array}{l}\text { RM 10m- } \\
\text { RM } 25 \mathrm{~m}\end{array}$ & 0 & $\$ 1 \mathrm{~m}$ & 0 & $\begin{array}{l}\text { 1bn RUB } \\
\max \end{array}$ & $\begin{array}{l}\text { Rs60- } \\
99 \mathrm{~m}\end{array}$ & $\begin{array}{l}\text { Y30- } \\
\text { Y300m }\end{array}$ & $\begin{array}{l}\mathrm{R} 4,5 \mathrm{~m}- \\
\mathrm{R} 50 \mathrm{~m}\end{array}$ \\
\hline
\end{tabular}

Sumber: NCR (2011) dan EG (2012) 
Usaha mikro, kecil dan menengah dalam mempertahankan eksistensinya dan mengembangkan usahanya sering mengalami banyak kendala. Menurut Eria (2014) usaha kecil dan menengah di negara-negara ASEAN dilaporkan mempunyai kesulitan di dalam mengakses sumber keuangan, teknologi dan pasar yang kompetitif. Kewirausahaan, kepatuhan terhadap standar, pemasaran dan manajemen juga merupakan beberapa masalah yang dihadapi oleh usaha kecil dan menengah di negaranegara ASEAN. Masalah lain yang tidak kalah pentingnya dalam mempertahankan eksistensi dan pengembangan usaha adalah ketidakmampuan pengelola usaha mikro, kecil dan menengah untuk mengukur kinerja usahanya. Yang sering terjadi adalah usaha mikro, kecil dan menengah tidak mengetahui apakah usahanya mengalami kemajuan atau kemuduran.

Menurut Ademola et al. (2013) dalam Dawuda and Azeko (2015), pencatatan akuntansi yang diselenggarakan dengan baik merupakan suatu yang sangat penting untuk pertumbuhan dan eksistensi suatu bisnis. Ikem et al. (2012) menyatakan, umumnya bukti empiris yang tersedia dalam literatur dari negara-negara maju mengungkapkan bahwa penggunaan informasi akuntansi pada usaha mikro, kecil dan menengah sangat buruk. Pada dasarnya usaha mikro, kecil, dan menengah yang belum mempunyai kemampuan untuk melakukan pencatatan akuntansi yang baik dan berkualitas, sebagai langkah awal dapat melaksanakan pencatatan akuntansi dengan single entry system dalam bentuk yang paling sederhana. Walaupun tidak dapat menghasilkan laporan keuangan yang lengkap seperti pada penggunaan double entry system namun penggunaan single entry system dapat menjadi langkah awal dan transisi menuju penggunaan double entry system.
Dari uraian di atas nampak bahwa untuk usaha mikro dan kecil diharapkan dapat melakukan pencatatan akuntansi atas semua transaksi keuangan yang terjadi minimal dengan menggunakan single entry system. Sedangkan sistem pengakuan pendapatan dan biaya dapat menggunakan basis akuntansi kas. Dengan demikian usaha mikro dan kecil dapat menyusun Laporan Perhitungan Laba Rugi yang dapat menunjukkan kinerja usaha pada saat tahun berjalan serta kemajuan dan kemunduran usaha dengan membandingkannya dengan Laporan Perhitungan Laba Rugi tahun sebelumnya.

\section{Pengembangan Hipotesis}

Berdasarkan uraian di atas dan permasalahan yang telah dirumuskan di atas, maka akan diajukan hipotesis sebagai berikut:

Ha0 : Usaha mikro dan kecil di Kampung Roti, Surabaya sebanyak 75\% tidak melakukan pencatatan data transaksi keuangan.

Ha1 : Usaha mikro dan kecil di Kampung Roti, Surabaya tidak sebanyak 75\% melakukan pencatatan data transaksi keuangan.

Hbo : Usaha mikro dan kecil di Kampung Roti, Surabaya sebanyak 75\% berpendapat pencatatan data transaksi keuangan secara signifikan tidak bermanfaat untuk mengukur kinerja usaha.

Hb1 : Usaha mikro dan kecil di Kampung Roti, Surabaya tidak sebanyak $75 \%$ berpendapat pencatatan data transaksi keuangan secara signifikan tidak bermanfaat untuk mengukur kinerja usaha.

Hc0 : Usaha mikro dan kecil di Kampung Roti, Surabaya sebanyak 75\% berpendapat pencatatan data transaksi keuangan secara signifikan tidak bermanfaat untuk keperluan mengajukan kredit. 
Hc1 : Usaha mikro dan kecil di Kampung Roti, Surabaya tidak sebanyak $75 \%$ berpendapat pencatatan data transaksi keuangan secara signifikan tidak bermanfaat untuk keperluan mengajukan kredit.

Hd0 : Usaha mikro dan kecil di Kampung Roti, Surabaya sebanyak 75\% berpendapat pencatatan data transaksi keuangan secara signifikan tidak bermanfaat untuk keperluan perpajakan.

Hd1 : Usaha mikro dan kecil di Kampung Roti, Surabaya tidak sebanyak $75 \%$ berpendapat pencatatan data transaksi keuangan secara signifikan tidak bermanfaat untuk keperluan perpajakan.

He0 : Usaha mikro dan kecil di Kampung Roti, Surabaya berpendapat tidak ada hubungan secara signifikan antara pencatatan data transaksi keuangan dengan mengukur kinerja usaha.

He1 : Usaha mikro dan kecil di Kampung Roti, Surabaya berpendapat ada hubungan secara signifikan antara pencatatan data transaksi keuangan dengan mengukur kinerja usaha.

Hfo : Usaha mikro dan kecil di Kampung Roti, Surabaya berpendapat tidak ada hubungan secara signifikan antara pencatatan data transaksi keuangan dengan keperluan mengajukan kredit.

Hf1 : Usaha mikro dan kecil di Kampung Roti, Surabaya berpendapat ada hubungan secara signifikan antara pencatatan data transaksi keuangan dengan keperluan mengajukan kredit.

Hg0 : Usaha mikro dan kecil di Kampung Roti, Surabaya berpendapat tidak ada hubungan secara signifikan antara pencatatan data transaksi keuangan dengan keperluan perpajakan.

Hg1 : Usaha mikro dan kecil di Kampung Roti, Surabaya berpendapat ada hubungan secara signifikan antara pencatatan data transaksi keuangan dengan keperluan perpajakan.

\section{Metode Penelitian}

Penelitian yang dilakukan adalah penelitian terapan (applied reserach) yang eksplanatori dengan tujuan untuk menguji hipotesis. Pada penelitian ini akan diteliti apakah sebanyak 75\% usaha mikro dan kecil di KampungRoti, Surabaya tidak melakukan kegiatan pencatatan transaksi keuangan dan bagi mereka apakah pencatatan data transaksi keuangan bermanfaat dan ada hubungannyadengan usaha untuk mengukur kinerja usaha, keperluan mengajukan kredit dan keperluan perpajakan.

Jenis data yang digunakan adalah data primer. Sumber data diperoleh dari jawaban kuesioner dan keterangan lainnya dari responden, yaitu para pengusaha mikro dan kecil di Kampung Roti, Surabaya. Prosedur pengumpulan data dilakukan dengan menggunakan kuesioner. Kuesioner yang diedarkan terdiri atas 2 bagian yaitu: bagian pertanyaan awal dan bagian pertanyaan utama. Penelitian ini tidak menggunakan seluruh data populasi, tetapi mengambil sebagian data populasi yang akan dijadikan sebagai sampel. Jumlah populasi pengusaha mikro dan kecil di Kampung Roti, Surabaya ada 65 pengusaha diambil sampel sebanyak 38 pengusaha (58,5\%). Pengambilan sampel dilakukan secara acak (random).

\section{Pembahasan}

Profil responden yang menjadi sampel berdasarkan jenis kelamin seperti terlihat pada Tabel 2. Tabel 3 menunjukkan profil responden berdasarkan usia. Tabel 4 menunjukkan profil responden berdasarkan sta-tus perkawinan. Tabel 5 menunjukkan profil responden berdasarkan tingkat pen-didikan. 
Tabel 2. Profil Responden Berdasarkan Jenis Kelamin

\begin{tabular}{|l|c|c|}
\hline \multicolumn{1}{|c|}{$\begin{array}{c}\text { Jenis Kelamin } \\
\text { Responden }\end{array}$} & $\begin{array}{c}\text { Jumlah } \\
\text { Responden }\end{array}$ & $\begin{array}{c}\text { Persentase } \\
\text { (\%) }\end{array}$ \\
\hline Laki-laki & 2 & 5,26 \\
\hline Perempuan & 36 & 94,74 \\
\hline Total & 38 & 100 \\
\hline
\end{tabular}

Sumber: Data Diolah

Tabel 3. Profil Responden Berdasarkan Usia

\begin{tabular}{|l|c|c|}
\hline \multicolumn{1}{|c|}{ Usia Responden } & $\begin{array}{c}\text { Jumlah } \\
\text { Responden }\end{array}$ & $\begin{array}{c}\text { Persentase } \\
(\%)\end{array}$ \\
\hline$<17$ tahun & 0 & 0 \\
\hline 17 tahun dan $<25$ tahun & 0 & 0 \\
\hline 25 tahun dan $<35$ tahun & 6 & 15,79 \\
\hline 35 tahun dan $<45$ tahun & 13 & 34,21 \\
\hline 45 tahun dan $<55$ tahun & 14 & 36,84 \\
\hline 55 tahun & 5 & 13,16 \\
\hline Total & 38 & 100 \\
\hline
\end{tabular}

Sumber: Data Diolah

Tabel 4. Profil Responden Berdasarkan Status Perkawinan

\begin{tabular}{|l|c|c|}
\hline $\begin{array}{c}\text { Status } \\
\text { Perkawinan } \\
\text { Responden }\end{array}$ & $\begin{array}{c}\text { Jumlah } \\
\text { Responden }\end{array}$ & $\begin{array}{c}\text { Persentase } \\
(\%)\end{array}$ \\
\hline Tidak Kawin & 1 & 2,63 \\
\hline Kawin & 36 & 94,74 \\
\hline Janda/Duda & 1 & 2,63 \\
\hline Total & 38 & 100 \\
\hline
\end{tabular}

Sumber: Data Diolah

Tabel 5. Profil Responden Berdasarkan Tingkat Pendidikan

\begin{tabular}{|l|c|c|}
\hline \multicolumn{1}{|c|}{$\begin{array}{c}\text { Tingkat Pendidikan } \\
\text { Responden }\end{array}$} & $\begin{array}{c}\text { Jumlah } \\
\text { Responden }\end{array}$ & $\begin{array}{c}\text { Persentase } \\
(\mathbf{\%})\end{array}$ \\
\hline SD & 9 & $23,68 \%$ \\
\hline SMP & 10 & $26,32 \%$ \\
\hline SMA & 15 & $39,47 \%$ \\
\hline Diploma & 1 & $2,63 \%$ \\
\hline S1 & 3 & $7,90 \%$ \\
\hline Total & 38 & 100 \\
\hline
\end{tabular}

Sumber: Data Diolah 
Tabel 6. Profil Responden Berdasarkan Lama Usaha

\begin{tabular}{|l|c|c|}
\hline \multicolumn{1}{|c|}{ Lama Usaha Responden } & $\begin{array}{c}\text { Jumlah } \\
\text { Responden }\end{array}$ & $\begin{array}{c}\text { Persentase } \\
\mathbf{( \% )}\end{array}$ \\
\hline$<1$ tahun & 0 & 0 \\
\hline 1 tahun dan $<3$ tahun & 4 & 10,52 \\
\hline 3 tahun dan $<5$ tahun & 6 & 15,79 \\
\hline 5 tahun dan $<10$ tahun & 8 & 21,05 \\
\hline 10 tahun dan $<15$ tahun & 10 & 26,32 \\
\hline 15 tahun & 10 & 26,32 \\
\hline Total & 38 & 100 \\
\hline
\end{tabular}

Sumber: Data Diolah

Tabel 7. Profil Responden Berdasarkan Jumlah Kekayaan (Tidak Termasuk Tanah dan Bangunan)

\begin{tabular}{|l|c|c|}
\hline \multicolumn{1}{|c|}{$\begin{array}{c}\text { Jumlah Kekayaan } \\
\text { (Rp.) }\end{array}$} & $\begin{array}{c}\text { Jumlah } \\
\text { Responden }\end{array}$ & $\begin{array}{c}\text { Persentase } \\
(\%)\end{array}$ \\
\hline$<10$ juta & 35 & 92,11 \\
\hline 10 juta dan $<25$ juta & 1 & 2,63 \\
\hline 25 juta dan $<50$ juta & 1 & 2,63 \\
\hline 50 juta dan $<200$ juta & 1 & 2,63 \\
\hline 200 juta dan $<350$ juta & 0 & 0 \\
\hline 350 juta dan $<500$ juta & 0 & 0 \\
\hline Total & 38 & 100 \\
\hline
\end{tabular}

Sumber: Data Diolah

Tabel 8. Profil Responden Berdasarkan Jumlah Penjualan Per Tahun

\begin{tabular}{|l|c|c|}
\hline Jumlah Penjualan per-tahun (Rp.) & $\begin{array}{c}\text { Jumlah } \\
\text { Responden }\end{array}$ & $\begin{array}{c}\text { Persentase } \\
(\mathbf{\%})\end{array}$ \\
\hline$<180$ juta & 34 & 89,48 \\
\hline 180 juta dan $<300$ juta & 2 & 5,26 \\
\hline 300 juta dan $<900$ juta & 1 & 2,63 \\
\hline 900 juta dan $<1,5$ milyar & 1 & 2,63 \\
\hline 1,5 milyar dan $<2,5$ milyar & 0 & 0 \\
\hline Total & 38 & 100 \\
\hline
\end{tabular}

Sumber: Data Diolah 
Tabel 6 menunjukkan profil responden berdasarkan lamanya kegiatan usaha yang telah dijalankan. Tabel 7 menunjukkan profil responden berdasarkan jumlah kekayaan tidak termasuk tanah dan bangunan. Tabel 8 menunjukkan profil responden berdasarkan jumlah penjualan per tahun.

\section{Pengujian dan Analisis Hasil Penelitian}

1. Pengujian dan Analisis Pencatatan Data Transaksi Keuangan

Hasil pengujian mendapatkan nilai uji chi-square sebesar 0,877 dengan $\mathrm{df}=$ 1. Sedangkan nilai dari tabel chi-square untuk $\mathrm{df}=1$ dan tingkat kepercayaan 0,05 (5\%) sebesar 3,841. Karena nilai dari uji chi-square sebesar 0,877 lebih kecil dari nilai tabel chi-square sebesar 3,841, maka berarti Ha0 diterima dan Ha1 ditolak. Penerimaan atau penolakan Ha0 dan Ha1 juga dapat diketahui dengan melihat nilai dari $p$-value. Hasil pengujian menunjukkan nilai $p$-value $=0,349$ lebih besar dari tingkat kepercayaan 0,05, maka berarti menerima Ha0 dan menolak Ha1.

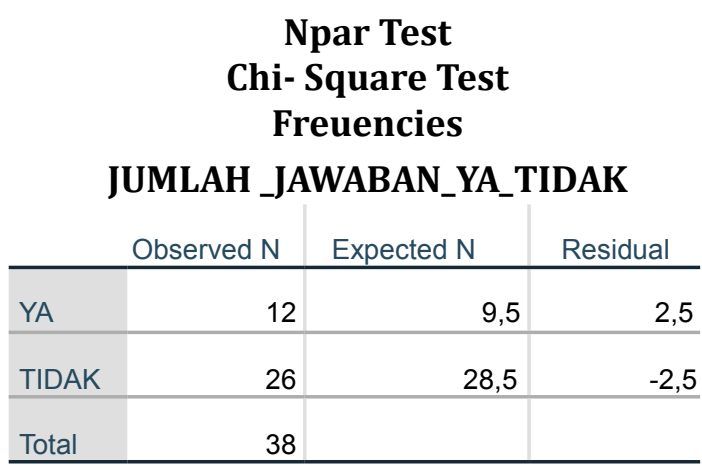

Test Statistics

\section{Jumlah Jawaban YA TIDAK}

\begin{tabular}{lr}
\hline Chi-Square &, $877^{\mathrm{a}}$ \\
\hline df & 1 \\
\hline Asymp. Sig. &, 349 \\
\hline
\end{tabular}

a. 0 cells $(0,0 \%)$ have expected frequencies less than 5 . The minimum expected cell frequency is 9,5
2. Pengujian Manfaat Pencatatan Transaksi Keuangan untuk Pengukuran Kinerja Usaha

Hasil pengujian mendapatkan nilai uji chi-square sebesar 1,719 dengan $\mathrm{df}=$ 1. Sedangkan nilai dari tabel chi-square untuk $\mathrm{df}=1$ dan tingkat kepercayaan $0,05(5 \%)$ sebesar 3,841. Karena nilai dari uji chi-square sebesar 1,719 lebih kecil dari nilai tabel chi-square sebesar 3,841, maka berarti $\mathrm{Hb} 0$ diterima dan $\mathrm{Hb} 1$ ditolak. Penerimaan atau penolakan $\mathrm{Hb} 0$ dan $\mathrm{Hb} 1$ juga dapat diketahui dengan melihat nilai dari $p$-value. Hasil pengujian menunjukkan nilai $p$-value $=0,190$ lebih besar dari tingkat kepercayaan 0,05 , maka berarti menerima $\mathrm{Hb} 0$ dan menolak $\mathrm{Hb} 1$.

\begin{tabular}{|c|c|c|c|}
\hline \multicolumn{4}{|c|}{$\begin{array}{c}\text { Npar Test } \\
\text { Chi- Square Test } \\
\text { Freuencies }\end{array}$} \\
\hline & Observed N & Expected N & Residual \\
\hline YA & 13 & 9,5 & 3,5 \\
\hline TIDAK & 25 & 28,5 & $-3,5$ \\
\hline Total & 38 & & \\
\hline
\end{tabular}

Test Statistics

\begin{tabular}{lr}
\multicolumn{2}{c}{ Jumlah Jawaban YA TIDAK } \\
\hline Chi-Square & \multicolumn{1}{c}{$1,719^{\mathrm{a}}$} \\
\hline df & 1 \\
\hline Asymp. Sig. &, 190 \\
\hline
\end{tabular}

a. 0 cells $(0,0 \%)$ have expected frequencies less than 5 . The minimum expected cell frequency is 9,5

3. Pengujian Manfaat Pencatatan Transaksi Keuangan untuk Keperluan Mengajukan Kredit

Hasil pengujian mendapatkan nilai uji chi-square sebesar 0,877 dengan $\mathrm{df}=$ 1. Sedangkan nilai dari tabel chi-square 
untuk $\mathrm{df}=1$ dan tingkat kepercayaan 0,05 (5\%) sebesar 3,841. Karena nilai dari uji chi-square sebesar 0,877 lebih kecil dari nilai tabel chi-square sebesar 3,841 , maka berarti Hc0 diterima dan Hc1 ditolak. Penerimaan atau penolakan $\mathrm{Hc} 0$ dan Hc1 juga dapat diketahui dengan melihat nilai dari $p$-value. Hasil pengujian menunjukkan nilai $p$-value $=0,349$ lebih besar dari tingkat kepercayaan 0,05, maka berarti menerima Hco dan menolak Hc1.

Npar Test

Chi- Square Test

Freuencies

JUMLAH _JAWABAN_YA_TIDAK

\begin{tabular}{lr|r|r} 
& Observed N & Expected N & Residual \\
\hline YA & 7 & 9,5 & $-2,5$ \\
\hline TIDAK & 31 & 28,5 & 2,5 \\
\hline Total & 38 & & \\
\hline
\end{tabular}

Test Statistics

Jumlah Jawaban YA TIDAK

\begin{tabular}{lr}
\hline Chi-Square &, $877^{\mathrm{a}}$ \\
\hline df & 1 \\
\hline Asymp. Sig. &, 349 \\
\hline
\end{tabular}

a. 0 cells $(0,0 \%)$ have expected frequencies less than 5 . The minimum expected cell frequency is 9,5

4. Pengujian Manfaat Pencatatan Transaksi Keuangan untuk Keperluan Perpajakan Hasil pengujian mendapatkan nilai uji chi-square sebesar 2,842 dengan $\mathrm{df}=$ 1. Sedangkan nilai dari tabel chi-square untuk df = 1 dan tingkat kepercayaan $0,05(5 \%)$ sebesar 3,841. Karena nilai dari uji chi-square sebesar 2,842 lebih kecil dari nilai tabel chi-square sebesar 3,841, maka berarti $\mathrm{Hd}_{0}$ diterima dan Hd1 ditolak. Penerimaan atau penolakan $\mathrm{Hd} 0$ dan $\mathrm{Hd} 1$ juga dapat diketahui dengan melihat nilai dari $p$-value. Hasil pengujian menunjukkan nilai $p$-value $=0,092$ lebih besar dari tingkat kepercayaan 0,05 , maka berarti menerima $\mathrm{Hd} 0$ dan menolak $\mathrm{Hd} 1$.

\section{Npar Test}

Chi-Square Test

Freuencies

JUMLAH _JAWABAN_YA_TIDAK

\begin{tabular}{lr|r|r} 
& Observed N & Expected N & Residual \\
\hline YA & 5 & 9,5 & $-4,5$ \\
\cline { 2 - 4 } TIDAK & 33 & 28,5 & 4,5 \\
\hline Total & 38 & & \\
\hline
\end{tabular}

Test Statistics

\begin{tabular}{lr} 
Jumlah Jawaban YA TIDAK \\
\hline Chi-Square & $2,842^{\mathrm{a}}$ \\
\hline df & 1 \\
\hline Asymp. Sig. &, 092 \\
\hline
\end{tabular}

a. 0 cells $(0,0 \%)$ have expected frequencies less than 5 . The minimum expected cell frequency is 9,5

5. Pengujian Hubungan Pencatatan Transaksi Keuangan dengan Pengukuran Kinerja Usaha

Hasil pengujian mendapatkan nilai uji chi-square sebesar 33,728 dengan $\mathrm{df}=$ 1. Sedangkan nilai dari tabel chi-square untuk $\mathrm{df}=1$ dan tingkat kepercayaan $0,05(5 \%)$ sebesar 3,841. Karena nilai dari uji chi-square sebesar 33,728 lebih besar dari nilai tabel chi-square sebesar 3,841, maka berarti Heo ditolak dan He1 diterima. Penerimaan atau penolakan $\mathrm{He} 0$ dan $\mathrm{He} 1$ juga dapat diketahui dengan melihat nilai dari $p$-value. Hasil pengujian menunjukkan nilai $p$-value $=$ 
0,000 lebih kecil dari tingkat kepercayaan 0,05 , maka berarti menolak He0 dan menerima He1 (Lampiran 1).

6. Pengujian Hubungan Pencatatan Transaksi Keuangan dengan Keperluan Mengajukan Kredit

Hasil pengujian mendapatkan nilai uji chi-square sebesar 6,306 dengan $\mathrm{df}=$ 1. Sedangkan nilai dari tabel chi-square untuk df = 1 dan tingkat kepercayaan $0,05(5 \%)$ sebesar 3,841. Karena nilai dari uji chi-square sebesar 6,306 lebih besar dari nilai tabel chi-square sebesar 3,841, maka berarti Hfo ditolak dan Hf1 diterima. Penerimaan atau penolakan Hfo dan Hf1 juga dapat diketahui dengan melihat nilai dari $p$-value. Hasil pengujian menunjukkan nilai $p$-value $=0,012$ lebih kecil dari tingkat kepercayaan 0,05, maka berarti menolak Hfo dan menerima $\mathrm{Hf}_{1}$ (Lampiran 2).

7. Pengujian Hubungan Pencatatan Transaksi Keuangan dengan Keperluan Perpajakan

Hasil pengujian mendapatkan nilai uji chi-square sebesar 12,475 dengan $\mathrm{df}=$ 1. Sedangkan nilai dari tabel chi-square untuk $\mathrm{df}=1$ dan tingkat kepercayaan $0,05(5 \%)$ sebesar 3,841. Karena nilai dari uji chi-square sebesar 12,475 lebih besar dari nilai tabel chi-square sebesar 3,841, maka berarti Hg0 ditolak dan Hg1 diterima. Penerimaan atau penolakan Hg0 dan Hg1 juga dapat diketahui dengan melihat nilai dari $p$-value. Hasil pengujian menunjukkan nilai $p$-value $=$ 0,000 lebih kecil dari tingkat kepercayaan 0,05, maka berarti menolak $\mathrm{Hg} 0$ dan menerima Hg1 (Lampiran 3).

\section{Simpulan}

Hasil penelitian menemukan 75\% usaha mikro dan kecil tidak melakukan pencatatan data transaksi keuangan. Penelusuran lebih lanjut menunjukkan bahwa usaha mikro dan kecil tidak melakukan pencatatan data transaksi keuangan karena menganggap tidak memberikan manfaat atau memberikan keuntungan bagi kegiatan usaha mereka dan kendala teknis untuk melaksanakan pencatatan data transaksi keuangan.

\section{Implikasi}

Hasil penelitian yang menunjukkan sebagian besar usaha mikro dan kecil tidak melakukan pencatatan data transaksi keuangan akan menyebabkan usaha mikro dan kecil tidak akan mampu untuk menghitung laba atau rugi yang diperoleh dari usaha secara benar. Hal ini tentu saja menjadi salah satu faktor yang menghambat usaha mikro dan kecil untuk mengembangkan usahanya, terutama untuk memperoleh pendanaan guna perluasan usaha.

\section{Rekomendasi}

Pihak pemerintah dalam hal ini Dinas Koperasi dan Usaha Kecil dan Menengah di daerah kota/kabupaten dan provinsi di bawah koordinasi Kementerian Koperasi dan Usaha Kecil dan Menengah harus secara intensif melakukan sosialisasi kepada usaha mikro, kecil, dan menengah mengenai pentingnya pencatatan data transaksi keuangan. 


\section{Daftar Pustaka}

Ademola, G. Olukotun, Samuel O. James and Ifedolapo Olore. 2012. The Roles of Record Keeping in The Survival and Growth of Small Scale Enterprises in Ijumu Local Government Area of Kogi State. Global Journal of Management and Business Research, Vol. 12, Issue 13, page 55-66.

Akesinro, Sunday Abayomi and Jonathan Adegoke Adetoso. 2016. The Imperatives of Accounting and Financial Records in The Development of Small Scale Enterprises in Nigeria. Research Journal of Finance and Accounting, Vol. 7, No. 14, page 43-52.

Bellefleur, Daniel, Zahra Murad and Patrick Tangkau. 2012. A Snapshot of Indonesian Entrepreneurship and Micro, Small and Medium Sized Enterprise Development. United States Agency International Development (USAID).

Berry, Albert. 2007. The Importance of SMEs in The Economy, International Tax Dialogue Global Conference on Taxation of SME, Buenos Aires, Argentina.

Dawuda, Abudu and Ibrahim Azeko. 2015. An Assessment of Financial Records Keeping Behaviour of Small Scale Business in Ghana: A Case Study of Bolgatanga Municipality. International Journal of Finance and Accounting, Vol. 4, No. 3, page 187-194.

EG (Edinburgh Group). 2012. Growing The Global Economy Through SMEs.

Eria. 2014. ASEAN SME Policy Index 2014: Towards Competitive and Innovative ASEAN SMEs, ASEAN SME Agencies Working Group.

Habaradas, Raymund Basco. 2009. The Challenges of SME Innovation and Technology Upgrading in Developing Economies: Insights from Malaysia, Thailand and The Philippines. Journal of International Business Research, Vol. 8.

IFC (International Finance Corporation). 2016. Women-Owned SMEs in Indonesia: A Golden Opportunity for Local Financial Institution, Market Research Study, Frankfurt School of Finance \& Management, Sonnemannstrasse 9-1160314, Frankfurt.

Ikem, Ohachosim Celestine, Onwuchekwa Faith Chidi and Ifeanyi Toochukwu Titus. 2012. Financial Challenges of Small and Medium-Sized Enterprises (SMEs) in Nigeria: The Relevance of Accounting Information, Review of Public Administration \& Management, Vol. 1, No. 2, page 248-276.

Madurapperuma, M.W., P.M.C. Thilakerathne and I.N. Manawadu. 2016. Accounting Record Keeping Practices in Small and Medium Sized Enterprise's (SME's) in Sri Lanka. Journal of Finance and Accounting, Vol. 4, No. 4, page 188-193.

NCR (National Credit Regulator). 2011. Literature Review on Small and Medium Enterprises' Access to Credit and Support in South Africa, Pretoria, South Africa.

OECD (Organisation for Economic Cooperation and Development). 2004. Promoting Enterpreneurship and Innovative SMEs in A Global Economy: Towards A More Responsible and Inclusive Globalisation, $2^{\text {nd }}$ Conference of Ministers Responsible for Small and Medium-Sized Enterprises (SMEs), Istambul, Turki.

Rahamon, Onaolapo Adekunle Abdul and Adegbite Tajudeen Adejare. 2014. The Analysis of The Impact of Accounting Records Keeping on The Performance of The Small Scale Enterprises. International Journal of Academic Research in Business and Social Sciences, Vol. 4, No. 1, page 1-17.

Sato, Yuri. 2015. Development of Small and medium Enterprises in The ASEAN Economies.

Undang-Undang Republik Indonesia Nomor 20 Tahun 2008 tentang Usaha Mikro, Kecil dan Menengah. 


\section{Lampiran 1}

\section{Crosstabs}

Case Processing Summary

\begin{tabular}{l|l|l|l|l|l|l|l} 
& \multicolumn{2}{c}{ Cases } \\
& \multicolumn{2}{c}{ Valid } & \multicolumn{2}{c|}{ Missing } & \multicolumn{2}{c}{ Total } \\
& N & Percent & N & Percent & N & Percent \\
\hline $\begin{array}{l}\text { PENCATATAN DATA TRANSAKSI } \\
\text { KEUANGAN * BERMANFAAT UNTUK }\end{array}$ & 38 & $100,0 \%$ & 0 & $0,0 \%$ & 38 & $100,0 \%$ \\
PENGUKURAN KINERJA USAHA & & & & & & \\
\hline
\end{tabular}

PENCATATAN DATA TRANSAKSI KEUANGAN * BERMANFAAT UNTUK PENGUKURAN KINERJA USAHA Crosstabulation Count

\begin{tabular}{llr|r|r} 
& & \multicolumn{2}{c|}{ BERMANFAAT UNTUK } & \\
& & PENGUKURAN KINERJA USAHA & \\
& & YA & TIDAK & \multicolumn{1}{c}{ Total } \\
\hline PENCATATAN DATA & YA & 12 & 0 & 12 \\
\cline { 2 - 6 } TRANSAKSI KEUANGAN & TIDAK & 1 & 25 & 26 \\
\cline { 3 - 6 } Total & & 13 & 25 & 38 \\
\hline
\end{tabular}

\begin{tabular}{|c|c|c|c|c|c|}
\hline & \multicolumn{3}{|c|}{ Chi-Square Tests } & \multirow[b]{2}{*}{$\begin{array}{c}\text { Exact Sig. } \\
\text { (2-sided) }\end{array}$} & \multirow[b]{2}{*}{$\begin{array}{l}\text { Exact Sig. } \\
\text { (1-sided) }\end{array}$} \\
\hline & Value & $\mathrm{Df}$ & $\begin{array}{c}\text { Asymptotic } \\
\text { Significance } \\
\text { (2-sided) }\end{array}$ & & \\
\hline Pearson Chi-Square & $33,728^{a}$ & 1 &, 000 & & \\
\hline Continuity Correction $^{b}$ & 29,591 & 1 &, 000 & & \\
\hline Likelihood Ratio & 40,347 & 1 &, 000 & & \\
\hline Fisher's Exact Test & & & &, 000 &, 000 \\
\hline Linear-by-Linear Association & 32,840 & 1 &, 000 & & \\
\hline $\mathrm{N}$ of Valid Cases & 38 & & & & \\
\hline
\end{tabular}

a. 1 cells $(25,0 \%)$ have expected count less than 5 . The minimum expected count is 4,11 .

b. Computed only for a $2 \times 2$ table 


\section{Crosstabs}

\section{Case Processing Summary}

\begin{tabular}{l|r|r|r|r|r|r} 
& \multicolumn{2}{c}{ Cases } \\
& Valid & \multicolumn{2}{c|}{ Missing } & \multicolumn{2}{c}{ Total } \\
& N & Percent & N & Percent & N & Percent \\
\hline $\begin{array}{l}\text { PENCATATAN DATA TRANSAKSI } \\
\text { KEUANGAN * BERMANFAAT UNTUK }\end{array}$ & 38 & $100,0 \%$ & 0 & $0,0 \%$ & 38 & $100,0 \%$ \\
MENGAJUKAN KREDIT & & & & & & \\
\hline
\end{tabular}

\section{CATATAN TRANSAKSI KEUANGAN * BERMANFAAT UNTUK MENGAJUKAN KREDIT Crosstabulation}

Count

\begin{tabular}{|c|c|c|c|c|}
\hline & \multicolumn{3}{|c|}{$\begin{array}{l}\text { BERMANFAAT UNTUK } \\
\text { MENGAJUKAN KREDIT }\end{array}$} & \multirow[b]{2}{*}{ Total } \\
\hline & & YA & TIDAK & \\
\hline PENCATATAN DATA & YA & 5 & 7 & 12 \\
\hline TRANSAKSI KEUANGAN & TIDAK & 2 & 24 & 26 \\
\hline Total & & 7 & 31 & 38 \\
\hline
\end{tabular}

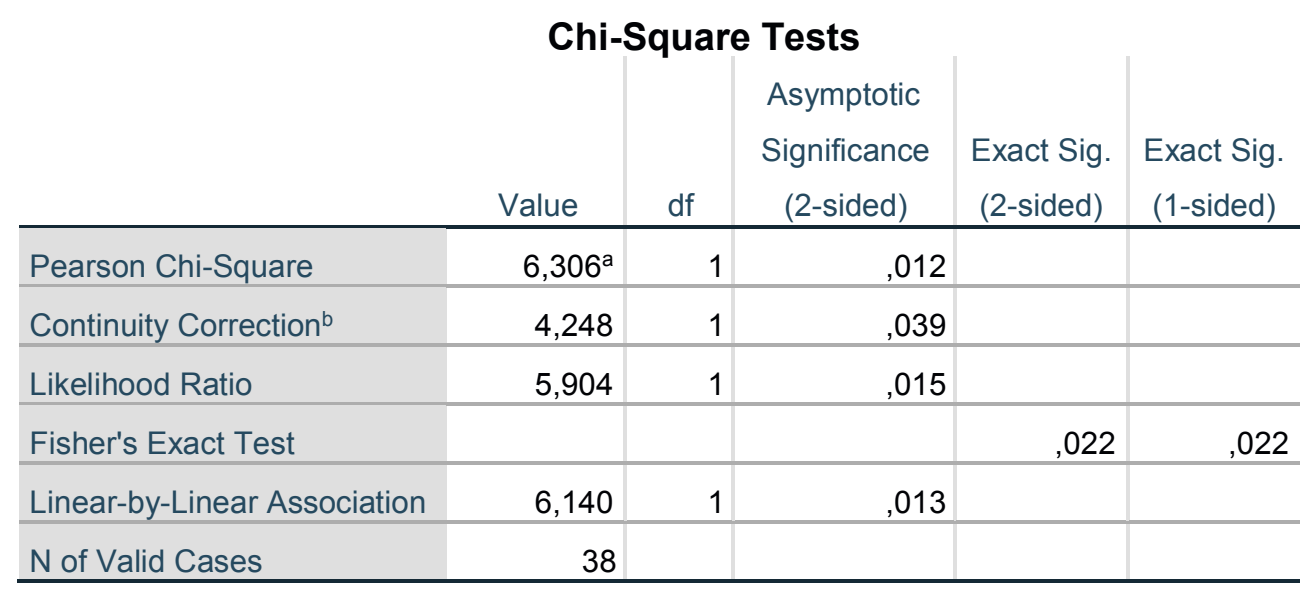

a. 2 cells $(50,0 \%)$ have expected count less than 5 . The minimum expected count is $2,21 \mathrm{~b}$. Computed only for a $2 \times 2$ table 


\section{Lampiran 3}

\section{Case Processing Summary}

\begin{tabular}{l|l|l|l|l|l|l|} 
& \multicolumn{2}{c}{ Valid } & \multicolumn{3}{c}{ Cases } \\
& N & Percent & N & Percent & N & Percent \\
\hline PENCATATAN DATA TRANSAKSI & 38 & $100,0 \%$ & 0 & $0,0 \%$ & 38 & $100,0 \%$ \\
KEUANGAN * BERMANFAAT UNTUK & & & & & & \\
KEPERLUAN PERPAJAKAN & & & & & & \\
\hline
\end{tabular}

\section{PENCATATAN DATA TRANSAKSI KEUANGAN * BERMANFAAT UNTUK KEPERLUAN PERPAJAKAN Crosstabulation}

Count

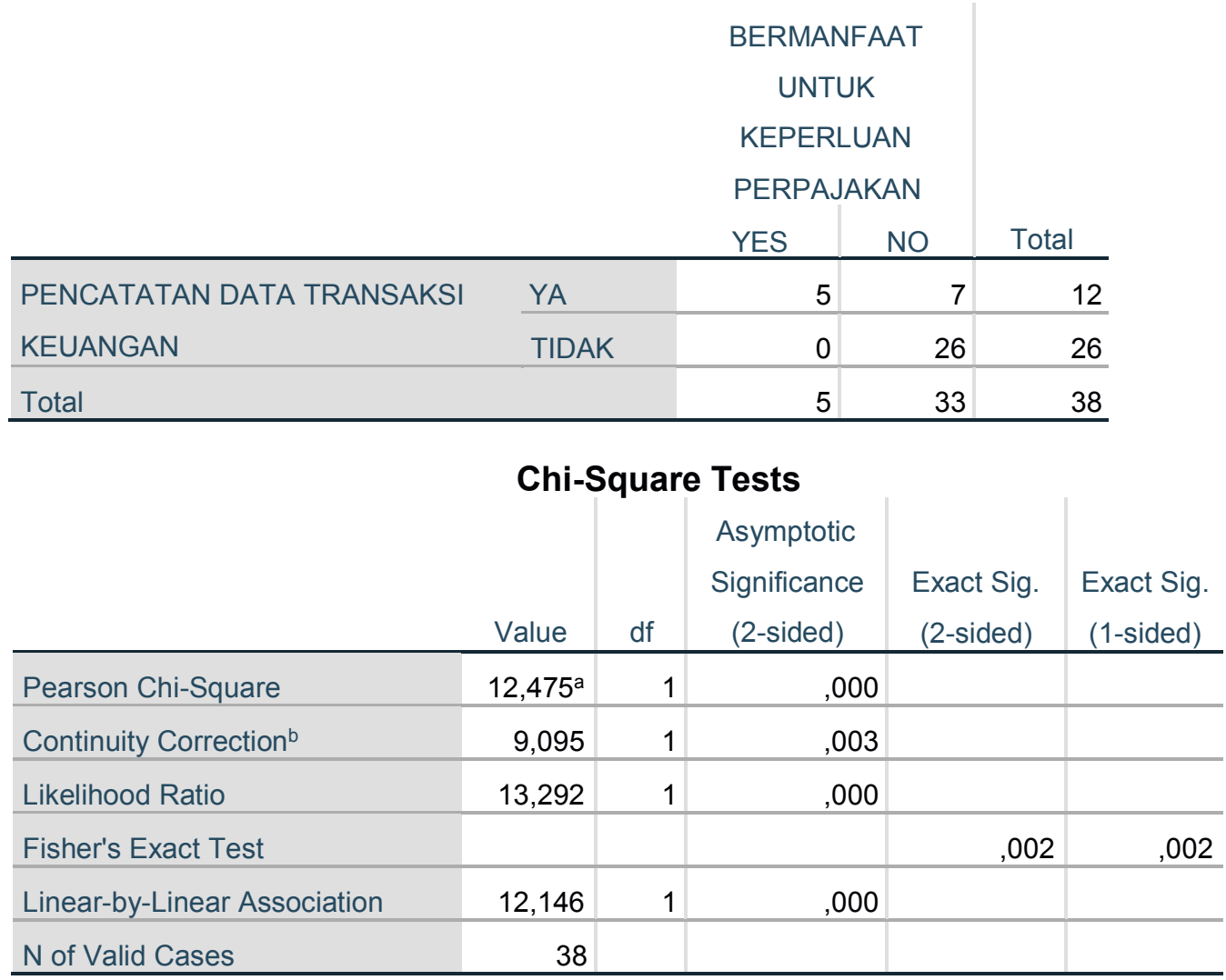

a. 2 cells $(50,0 \%)$ have expected count less than 5 . The minimum expected count is 1,58 .

b. Computed only for a $2 \times 2$ table 